\title{
Correlation of serum levels of anti-tumor necrosis factor agents with perianal fistula healing in Crohn's disease: a narrative review
}

\author{
Eron Fabio Miranda ${ }^{1}$, Rodrigo Bremer Nones ${ }^{2}$, Paulo Gustavo Kotze ${ }^{1}$ \\ ${ }^{1}$ Colorectal Surgery Unit, IBD Outpatient Clinics, Catholic University of Paraná (PUCPR), Curitiba, ${ }^{2}$ IBD Outpatient Clinics, Hospital Nossa \\ Senhora das Graças, Curitiba, Brazil
}

With the overspread use of measurement of serum levels of anti-tumor necrosis factor (TNF) agents (therapeutic drug monitoring, TDM), new therapeutic strategies have been used in the management of Crohn's disease (CD). Different targets are correlated with increased levels of circulating drugs. Recent evidence demonstrated that higher serum levels of anti-TNF agents may be associated to better outcomes in perianal fistulizing CD (PFCD). Overall, patients with healed fistulas had higher serum levels of infliximab and adalimumab as compared to those with active drainage. This was demonstrated in some cohort studies, in induction and maintenance, in adults and children with PFCD. In this narrative review, authors summarize current evidence on the use of serum level measurement of anti-TNF agents and its correlation with perianal fistula healing in CD patients. Data on the use of TDM in PFCD is discussed in detail. The retrospective design of the studies and the lack of objective parameters to measure fistula healing are the main limitations of published data. Prospective studies, with central reading of objective radiological parameters, such as pelvic magnetic resonance imaging scores, can improve the level of evidence on the possible advantages of TDM in perianal fistula in CD and are warranted. (Intest Res 2021;19:255-264)

Key Words: Crohn disease; Fistula; Tumor necrosis factor-alpha

\section{INTRODUCTION}

Crohn's disease (CD) is a chronic gastrointestinal condition, characterized by episodes of exacerbation of disease activity and periods of remission. ${ }^{1}$ Such chronicity can lead to several complications, such as strictures, fistulas, abscesses and perforation, with significant impairment in quality of life. ${ }^{2}$ Perianal fistulizing CD (PFCD) is a specific phenotype which represents a disease modifying element, usually associated to worse prognosis of the disease. PFCD can affect up to $1 / 3$ of

Received April 16, 2020. Revised June 11, 2020. Accepted June 26, 2020. Correspondence to Eron Fabio Miranda, Colorectal Surgery Unit, IBD Outpatient Clinics, Catholic University of Paraná (PUCPR), Rua Brasilio Itiberê, 3909 - Água Verde, Curitiba 80240-060, Brazil. Tel: +55-4133436459, Fax: +55-41-33436459, E-mail: eronfabiomiranda@gmail.com overall CD patients ${ }^{3}$ and more than $90 \%$ of patients with rectal involvement. ${ }^{4}$ The management of PFCD is multidisciplinary, with intensive medical therapy associated to multiple surgical procedures. This usually results in significant physical and psychological impact in patients' lives.

There are significant limitations of conventional medical treatment in PFCD (corticosteroids, immunosuppressants, and antibiotics). Fistula healing rates are low with this strategy and recurrence is frequent. ${ }^{5}$ Some prospective studies have demonstrated the efficacy of biologics in controlling perianal fistulas in CD. Present et al., ${ }^{6}$ in the first randomized controlled study with biologics for the treatment of fistulizing CD, demonstrated the effectiveness of infliximab (IFX) in closing abdominal and perianal fistulas. Sands et al., in the ACCENT 2 study, demonstrated the better efficacy of IFX as compared to 
placebo, in maintenance therapy in patients with perianal fistulas who responded to induction regimen with the drug. A meta-analysis over the treatment of PFCD with adalimumab (ADA), demonstrated complete closure of anal fistulas in $36 \%$ and partial response in $31 \%$ of patients. ${ }^{8}$ Other sub-analyses of pivotal phase III studies and some real-life studies have suggested similar efficacy of other anti-tumor necrosis factor (TNF) agents, such as $\mathrm{ADA}^{9,10}$ and certolizumab pegol in the management of this condition. ${ }^{11}$ There are scarce data with other biological agents, such as vedolizumab and ustekinum$a b$, in the management of PFCD.

Combination therapy with the use of biologics and surgical manipulation of fistula tracks, with sepsis eradication and seton placement, currently represents the best treatment strategy for PFCD. ${ }^{12}$ This strategy can lead to long term fistula closure when compared to surgical treatment alone. ${ }^{13}$

More recently, evidence demonstrated that higher serum levels of anti-TNF agents can be associated to better outcomes in $\mathrm{CD}$, such as higher rates of clinical remission and mucosal healing. ${ }^{14-16}$ With the possibility of measurement and monitoring of serum levels of anti-TNF agents, new therapeutic strategies have been recently used in the management of $\mathrm{CD}^{17}$ The optimal cutoff serum level of an anti-TNF may vary, depending on the agent and on the desired therapeutic target: clinical remission, mucosal or fistula healing. ${ }^{18}$ Specially in PFCD, there is data suggesting a correlation between higher serum levels of anti-TNF agents and fistula healing. This was demonstrated in some cohort studies with IFX and ADA, in induction and maintenance, in adults and children with $\mathrm{CD}^{19-24}$ The studies published to date are associated with some limitations, such as different outcome measurements, time periods of analysis and lack of objective markers of fistula healing. In general, patients with healed fistulas had higher serum levels of IFX (at trough) and ADA (measured between doses) as compared to those with active perianal disease. This leads to speculation that the fistulizing phenotype in CD may need more circulating active drug in order to control the disease, as compared to the luminal phenotype. This would place therapeutic drug monitoring (TDM) as an important tool in the management of complex perianal fistulas in $\mathrm{CD}$, in association to different surgical techniques.

The aim of this narrative review is to demonstrate and summarize the current evidence on the use of serum level measurement of anti-TNF agents and its correlation with perianal fistula healing in CD patients. Data on the use of TDM in PFCD is discussed in detail. Limitations of the studies over this topic will also be described, and a discussion of the need for objective parameters for future studies will also be highlighted.

\section{TDM IN IBD: CONCEPTS AND APPLICATIONS}

The concept of precision medicine in inflammatory bowel diseases (IBD) points out to the use of a specific drug to a single patient, at a determinate time, that can confer the highest chance of controlling disease activity, by inducing clinical, biological, endoscopic and/or histologic response or remission. ${ }^{25}$ In clinical practice, precision medicine could be classified in 2 phases. The first phase, which ideally should be pretreatment, refers to the choice of which drug to use. In this field, different aspects such as epidemiological, biological or genetic factors and gut microbiome interplay simultaneously, affecting the chance of response, or pharmacodynamic failure. Much of this knowledge is still in development and was revised elsewhere. ${ }^{26}$ Despite promising, the lack of validation and feasibility of specific tests limit their use nowadays. The second phase refers to the appropriate use of a chosen drug, which can be achieved by using TDM strategies, to prevent pharmacokinetic failures.

TDM in IBD is defined as the quantification of serum drug levels and/or antibody concentrations at a proper time point, which may guide the clinical assistant to take an appropriate action or dose adjustment during the treatment of a patient. ${ }^{27}$ It could be applied to both biological and nonbiological therapy in IBD. The rationale of performing such pharmacokinetic studies is based on the assumption that there is a good correlation between drug levels with response to a specific treatment. Most of these data come from observational and/or retrospective studies and suggest that the higher the level of a certain agent, the greater the chance of response. ${ }^{28-30}$ In contrast, the lower the level is observed, the greater is the chance of nonresponse and/or immunogenicity to biological therapy, mainly driven by the development of antibodies to the drug. ${ }^{31}$

There are 2 different strategies for the use of TDM in IBD. The first is "reactive" TDM, in which serum levels and/or antibodies are assessed in the clinical context of inadequate response or secondary loss of response, after failure of a specific therapy. The second is entitled "proactive" TDM, in which the quantification drug levels and/or antibodies is performed before failure, in all patients, allowing therapeutic adjustments to prevent both primary and secondary nonresponses. ${ }^{32}$

Currently, the use of reactive TDM may be of benefit as 
compared to empirical change of therapy, owing to a reduction in the duration of an ineffective therapy, lower overall costs and to an increase in quality of life after therapeutic adjustment, drug levels and endoscopic remission. ${ }^{33,34}$ There is still some uncertainty about the proper use of proactive TDM, once prospective trials comparing empirical or reactive changes in therapy demonstrated conflicting results. ${ }^{35-37}$ However, other studies suggest that the use of proactive TDM may be associated with higher clinical, biological and endoscopic response rates, longer persistence of therapy, less complications such as hospitalizations, surgery or infusion reactions due to immunogenicity. ${ }^{38-40}$ Proactive TDM either may be more cost-effective in simulation studies. ${ }^{41}$

Although there are different methods of measuring drug levels and antidrug concentrations, none may be considered as a gold standard. Thus, the choice of which one to use may be influenced by availability, price and local expertise. Despite analytical differences, these methods are not perfectly interchangeable, but there is adequate agreement in clinical classification and outcomes among different assays. ${ }^{42}$

Once there are substantial differences in dosing regimens and pharmacokinetics between intravenous and subcutaneous biologics, drug levels should be measured at different time points. For intravenous biologics, the concentration could be determined at peak, intermediate or trough phases. For subcutaneous biologics, the intermediate and trough moment could be used, and may not be interchangeable. It is still unclear which moment correlates with the best sensitivity. Currently, due to convenience, the trough level is mostly used in the majority of studies with IFX, while the intermediate moment is used in studies with ADA. ${ }^{43,44}$

The determination of antidrug antibodies is mostly performed in a scenario of inadequate or loss of response to biological therapy. If the assay used is drug sensitive, which means that it cannot detect antibodies in the presence of circulating drug, the most appropriate time for measurement of an antidrug antibody is just before the next dose (at trough). On the other hand, the use of drug tolerant assays, which could detect antibodies with circulating drug on board, still have an uncertain clinical benefit. ${ }^{45,46}$

The most challenging issues regarding TDM is which target level to reach, or what is the best therapeutic window. There is a great variety of factors that could influence the dose response relationship, so that one drug level cannot fit all endpoints for different drugs, diseases and patients, or even for the same patient at different moments. The greater the inflam- matory burden, the greater the level which is necessary to capture response. In other words, during induction therapy or in a scenario of extensive colitis, greater drug levels may be needed than during maintenance therapy with a stable condition, or in the treatment of a short inflammatory segment. Additionally, the greater the bowel damage along the course of the disease (inflammatory strictures or fistulizing disease), or the more precise the target is (histologic remission vs. clinical or endoscopic remission), the greater may be the levels possibly needed ${ }^{47}$ Unfortunately, for some patients, an adequate serum level may not correlate with clinical response, due to pharmacodynamic failure or due to individual variances. Most of the evidence with TDM comes from studies with luminal CD. As previously mentioned, in certain scenarios as extensive colitis or patients with low albumin, higher serum levels of the drugs may be needed in order to achieve remission. Thus, there is controversy if patients with fistulizing CD, with high inflammatory burden, may need higher levels of circulating drugs to achieve response or remission. Recently, data from retrospective studies outlined the association of higher serum levels of anti-TNF agents and higher healing rates of perianal fistulas in $\mathrm{CD}^{48}$ In the next section, these studies will be discussed in detail.

\section{PFCD AND SERUM LEVELS OF ANTI-TNF AGENTS: CURRENT EVIDENCE}

There are several studies in the literature which correlated the presence of higher serum levels of anti-TNF agents with higher rates of perianal fistulas healing in CD, with the use of IFX and ADA, in adult and pediatric patients, with different methodologies and analyses.

Davidov et al. ${ }^{19}$ conducted the first study correlating IFX and measurement of trough serum levels and anti-IFX antibodies (ATI) by the ELISA (enzyme-linked immunosorbent assay) method, in a retrospective observational cohort from 2 reference centers in Israel, with 36 patients. The primary outcome was to correlate IFX trough levels in induction therapy at weeks 2, 6, and 14, with evaluation of clinical response (decreased drainage of fistulas reported by the patient and validated by the physician) at weeks 14 and 30 . The authors observed that higher trough levels at weeks 2 and 6 and were independently associated with response and closure of fistulas at weeks 14 and 30. Numerically, trough levels $\geq 9.25 \mu \mathrm{g} / \mathrm{mL}$ at week 2 and $\geq 7.25 \mu \mathrm{g} / \mathrm{mL}$ at week 6 were the greatest predictors of response in perianal fistulas. Some limitations were ob- 
served in this analysis. This was a retrospective study with a relatively small cohort. They had to exclude patients with unavailable drug levels or incomplete clinical follow-up, which limited the study sample. An additional substantial limitation of the study was associated to the clinical nature of the followup, with only a few patients having repeated imaging tests (magnetic resonance imaging, MRI) to demonstrate radiographic healing. The strength of this study was based on the fact that it demonstrated a possible effect of the use of proactive TDM in PFCD for the very first time. Moreover, it demonstrated the importance of TDM in the induction phase in this phenotype of the disease.

Yarur et al. ${ }^{20}$ in a cross-sectional retrospective study, performed an analysis of trough levels of IFX in a larger cohort of patients ( $\mathrm{n}=117$ ) with PFCD, who evidently had one or more active fistula during IFX therapy, with a median follow-up of at least 24 weeks. Patients with regular doses of IFX and those with optimized regimens were included. The variables analyzed were demographic factors, disease activity, trough levels of IFX and ATI, among several others. The primary outcome of the study was fistula healing and the secondary outcomes were complete closure of the fistulas (absence of opening at the skin level) and rectal mucosal healing (absence of ulcers $>5 \mathrm{~mm}$ ). The median time of IFX use was 29 weeks and $63.2 \%$ of the patients were using an optimized dose. The median trough level of IFX in the whole group was $10 \mu \mathrm{g} / \mathrm{mL}$ and overall $14.5 \%$ of the patients had ATI. Closure of perianal fistulas occurred in $31 \%$ of patients, none of whom with positive ATI. Mucosal healing occurred in $46.1 \%$ of patients. The authors observed that patients with healed fistulas had significantly higher trough levels of IFX as compared to those without (15.8 $\mu \mathrm{g} / \mathrm{mL}$ vs. $4.4 \mu \mathrm{g} / \mathrm{mL} ; P<0.0001)$. There was an important incremental gain in healing of fistulas with higher levels of IFX. They observed that in order to obtain complete healing of fistulas, it was necessary to reach trough levels of IFX above 10 $\mu \mathrm{g} / \mathrm{mL}$, and in a minority of patients, healing was observed with levels above $20 \mu \mathrm{g} / \mathrm{mL}$. In addition, patients with positive ATIs had a lower chance of fistula healing (odds ratio [OR], 0.04; 95\% confidence interval [CI], 0.005-0.3; $P<0.001$ ). The authors concluded that optimization of the IFX regimen can potentially lead to better healing rates in PFCD, which can be done before considering the patient as a nonresponder to the agent due to persistent activity of the disease in the perianal area. The study had limitations. Patients could have proactive TDM, but most had a reactive strategy, what could represent a bias due to more severe patients with loss of response in the reactive scenario. Moreover, no classification of the fistulas in simple versus complex was detailed. Despite these limitations, this was the study with the largest sample of patients over the topic.

Strik et al. ${ }^{21}$ performed a retrospective cross-sectional study with PFCD patients undergoing maintenance therapy with IFX $(n=47)$ and ADA $(n=19)$, with measurement of serum levels and antidrug antibodies (ELISA). This was the first study to assess the correlation of serum levels in perianal fistulas in $\mathrm{CD}$ in patients under ADA therapy. Patients were allocated into 2 groups, based on the status of fistulizing perianal disease (active draining or inactive fistulas) at the time of treatment in which the blood sample was collected. Fistula closure was defined by clinical examination (no drainage after digital expression of fistula tracks) and by MRI (where fibrosis corresponded to fistula closure and absence of active disease). The time period between collection of serum levels, clinical examination and MRI did not exceed 4 weeks. IFX levels were collected immediately before infusion (trough levels) and ADA levels at any time between applications. No antidrug antibodies were identified in patients from both groups. Results were similar between the agents. Serum levels of the anti-TNF agents were significantly higher in patients with fistula closure as compared to those with active drainage in the IFX $(6.0 \mu \mathrm{g} /$ $\mathrm{mL}$ vs. $2.3 \mu \mathrm{g} / \mathrm{mL} ; P<0.001)$ and ADA groups $(7.4 \mu \mathrm{g} / \mathrm{mL}$ vs. $4.8 \mu \mathrm{g} / \mathrm{mL} ; P=0.003)$. Serum concentrations associated with fistula closure had a cutoff equal to or greater than $5 \mu \mathrm{g} / \mathrm{mL}$ for IFX (at trough) and $5.9 \mu \mathrm{g} / \mathrm{mL}$ for ADA. The authors concluded that patients with PFCD with active fistulas can benefit from optimized doses of anti-TNF agents. One important contribution from this study was that patients had MRI evaluation, an objective marker for outcome measurement.

Similar data were published in pediatric patients. El-Matary et al., ${ }^{22}$ in a prospective multicentric Canadian study, evaluated 27 pediatric patients (aged under 17 years) with PFCD, using conventional doses of IFX, who had measurement of trough levels performed before the fourth infusion at trough (week 14). The median IFX trough level in patients with clinical response was $12.7 \mu \mathrm{g} / \mathrm{mL}$ (range, $6.6-15.5 \mu \mathrm{g} / \mathrm{mL}$ ) as compared to $5.4 \mu \mathrm{g} / \mathrm{mL}$ (range, $2.7-8.4 \mu \mathrm{g} / \mathrm{mL}$ ) in patients with residual active disease $(P=0.02)$. There was a significant correlation between trough IFX levels at week 14 and healing of perianal fistulas at week $24(\mathrm{r}=0.65 ; P=0.0002)$. In univariate regression analysis, age, sex, and laboratory markers were not associated with fistula response at week 24 . Trough IFX levels were significantly associated with fistula response after 24 
weeks (OR, 1.2; 95\% CI, 1.00-1.29; $P=0.04)$. The area under receiver operating curve for IFX levels as a predictor of response in PFCD at week 24 was 0.80 (95\% CI, 0.64-0.97; $P=0.007$ ), and a level of $12.7 \mu \mathrm{g} / \mathrm{mL}$ was a significant predictor of fistula healing at week 24 with a sensitivity of 0.62 and specificity of 0.65. Authors concluded that after the induction phase, higher trough IFX levels were associated with a better outcome for PFCD healing in children.

Ruemmele et al., ${ }^{23}$ in a prospective study, also performed in pediatric patients with PFCD using ADA, where drug concentrations were measured at weeks 16 and 52, pointed out that there was no significant statistical difference in fistula healing rates in patients with standard versus high doses of ADA, despite a tendency towards better results in the higher dose. IMAgINE 1 was a 52-week, randomized, double-blind phase III clinical trial evaluating efficacy and safety of ADA in children/adolescents with moderate-to-severe CD. Patients from the overall study population with perianal fistulas at screening and baseline of the study were assessed in this current subanalysis. Fistula tracks were defined by draining cutaneous fistulae upon gentle compression during physical examination, without use of pelvic MRI. Fistula closure and fistula improvement were defined as closure of all baseline fistulae or a decrease in number by $\geq 50 \%$ in drainage, for at least 2 consecutive visits, respectively. Serum levels of ADA were obtained at weeks 16 and 52 in the 36 patients analyzed (mean age, 14.4 years). Median serum levels of ADA in patients with fistula closure at weeks 16 and 52 were $7.4 \mu \mathrm{g} / \mathrm{mL}$ (range, 1.2$23.2 \mu \mathrm{g} / \mathrm{mL}$ ) and $7.5 \mu \mathrm{g} / \mathrm{mL}$ (range, 1.5-26.6 $\mu \mathrm{g} / \mathrm{mL}$ ), respectively. The respective values for patients with no fistula closure at same periods were $6.4 \mu \mathrm{g} / \mathrm{mL}$ (range, $1.1-17.4 \mu \mathrm{g} / \mathrm{mL}$ ) and $5.6 \mu \mathrm{g} / \mathrm{mL}$ (range, 1.2-20.7 $\mu \mathrm{g} / \mathrm{mL}$ ). No statistical difference was identified, and this questioned if higher doses of ADA in children could lead to higher serum levels of the drug. Despite a multicentric pivotal study, this analysis failed to correlate serum levels and better outcomes, what was demonstrated in adults. The study was not powered to detect differences in fistula patients, and no imaging method was used. On the other hand, this was the study with larger sample of pediatric patients with perianal fistulas over this topic.

Plevris et al. ${ }^{24}$ performed a retrospective, cross-sectional analysis of serum levels and antidrug antibodies in 64 patients with PFCD who received IFX $(n=29)$ or ADA $(n=35)$ for at least 24 weeks, with the primary objective of identifying a possible correlation of higher serum levels (trough at IFX, at any time with ADA) and fistula healing (defined by the absence of drainage from fistula tracks in clinical examination 4 weeks after blood collection for serum level analyses). A secondary objective was to determine serum levels in patients with completely closed fistulas. For ADA patients, receiver operating characteristic (ROC) analysis identified a cutoff level of $\geq 6.8$ $\mu \mathrm{g} / \mathrm{mL}$ for fistula healing and $\geq 9.8 \mu \mathrm{g} / \mathrm{mL}$ for fistula closure. For IFX patients, ROC analysis identified an optimum trough level of $\geq 7.1 \mu \mathrm{g} / \mathrm{mL}$ for both fistula healing and closure. The authors concluded that higher maintenance levels of anti-TNF agents were associated with perianal fistula healing and closure in PFCD. Again, no pelvic MRI was used to better document fistula healing. This limitation, added to the retrospective nature of data collection, constituted some of the drawbacks of the study.

Table 1 summarizes the most important data in the literature from the previously described studies, which correlated serum levels of anti-TNF agents with healing of perianal fistulas in CD.

\section{DISCUSSION}

Perianal fistulas in CD constitute a heterogeneous phenotype of the disease. CD-related fistulas have 2 main components: an inflammatory (which is treated with medication) and a mechanical (treated with surgery). One component cannot be dissociated from another, as the approach needed is multidisciplinary. Currently, the management with intensive medical therapy (usually with anti-TNF agents as first line) and surgical drainage with curettage of fistula tracks and seton placement represents the best strategy to manage this difficult phenotype of the disease, and is recommended by most guidelines. $^{12,49}$ The principle of this combination management is targeted towards rectal mucosal healing and reduction of inflammation in fistula tracks, what can close fistulas in approximately $50 \%$ of patients. Once there is no rectal or local inflammation, and the fistula still persists, additional surgical procedures, such as advancement flaps, ligation of fistula tracks, among others, can be indicated. ${ }^{50}$ An essential condition for surgical attempts to close fistulas is the absence of inflammation. If active proctitis or inflamed fistula tracks are present, corrective surgery is contra-indicated. For this reason, it is important to aim a reduction in the inflammatory burden with all efforts in PFCD, in order to achieve better outcomes. For that purpose, anti-TNF agents constitute the most effective medical therapy available, as several limitations are associated with conventional therapy with immunomodulators or antibi- 
Table 1. Main Characteristics of Studies with Data Correlating Serum Levels of Anti-TNF Agents (Measured at Trough with IFX and at Any Moment with ADA) with Healing of Perianal Fistulas

\begin{tabular}{|c|c|c|c|c|c|c|c|c|c|}
\hline $\begin{array}{l}\text { Author } \\
\text { (year) }\end{array}$ & Population & $\begin{array}{c}\text { No. of } \\
\text { patients }\end{array}$ & $\begin{array}{l}\text { Timing } \\
\text { of } \\
\text { TDM }\end{array}$ & $\begin{array}{l}\text { Anti- } \\
\text { TNF } \\
\text { agent }\end{array}$ & $\begin{array}{l}\text { Outcome } \\
\text { definition }\end{array}$ & $\begin{array}{c}\text { Drug } \\
\text { concentration } \\
\text { in healed } / \mathrm{closed} \\
\text { fistulas }(\mu \mathrm{g} / \mathrm{mL})\end{array}$ & $\begin{array}{c}\text { Drug } \\
\text { concentration } \\
\text { in active fistulas } \\
(\mu \mathrm{g} / \mathrm{mL})\end{array}$ & $\begin{array}{l}\text { Target serum } \\
\text { level defined } \\
\text { for outcome } \\
(\mu \mathrm{g} / \mathrm{mL})\end{array}$ & Observations \\
\hline $\begin{array}{l}\text { Yarur et al. } \\
(2016)^{20}\end{array}$ & Adults & 117 & $N R$ & IFX & $\begin{array}{l}\text { Primary: fistula healing } \\
\text { (absence of drainage } \\
\text { and no seton) } \\
\text { Secondary: fistula closure } \\
\text { (no skin opening and } \\
\text { mucosal healing) }\end{array}$ & $15.8(9.9-27.0)$ & $4.4(0-9.8)$ & $\geq 10.1$ & $\begin{array}{l}\text { Single-center, } \\
\text { cross-sectional } \\
\text { retrospective } \\
\text { study }\end{array}$ \\
\hline $\begin{array}{l}\text { Strik et al. } \\
(2019)^{21}\end{array}$ & Adults & $\begin{array}{l}47 \text { IFX } \\
19 \text { ADA }\end{array}$ & NR & $\begin{array}{l}\text { IFX } \\
\text { ADA }\end{array}$ & $\begin{array}{l}\text { Fistula closure (no } \\
\text { drainage with finger } \\
\text { compression or fibrotic } \\
\text { tract at MRI) }\end{array}$ & $\begin{array}{l}6.0(5.4-6.9) \\
7.4(6.5-10.8)\end{array}$ & $\begin{array}{l}2.3(1.1-4.0) \\
4.8(1.7-6.2)\end{array}$ & $\begin{array}{l}\geq 5 \\
\geq 5.9\end{array}$ & $\begin{array}{l}\text { Single-center, } \\
\text { cross-sectional } \\
\text { retrospective } \\
\text { study }\end{array}$ \\
\hline $\begin{array}{l}\text { Davidov } \\
\text { et al. } \\
(2016)^{19}\end{array}$ & Adults & 36 & $\begin{array}{l}\text { wk } 2 \\
\text { wk } 6 \\
\text { wk } 14\end{array}$ & IFX & $\begin{array}{l}\text { Fistula closure (absence } \\
\text { of a previously detected } \\
\text { fistula opening) }\end{array}$ & $\begin{array}{c}20.0(16.2-26.3) \\
13.3(7.6-19.0) \\
4.1(0.7-5.7)\end{array}$ & $\begin{array}{l}5.6(2.8-9.2) \\
2.6(0.4-7.0) \\
0.1(0.01-2.3)\end{array}$ & $\begin{array}{l}\geq 9.25 \\
\geq 7.25 \\
\quad-\end{array}$ & $\begin{array}{l}2 \text { Centers, } \\
\text { retrospective } \\
\text { cohort study, } \\
\text { Proactive TDM }\end{array}$ \\
\hline $\begin{array}{l}\text { Ruemmele } \\
\text { et al. } \\
(2018)^{23}\end{array}$ & Pediatric & 36 & $\begin{array}{l}\text { wk } 16 \\
\text { wk } 52\end{array}$ & ADA & $\begin{array}{l}\text { Fistula closure (closure } \\
\text { of all baseline } \\
\text { fistulas) and fistula } \\
\text { improvement (decrease } \\
\text { in } \geq 50 \% \text { fistulas) in } 2 \\
\text { consecutive visits }\end{array}$ & $\begin{array}{r}7.4(1.8-13.0) \\
10.0(3.0-17.0)\end{array}$ & $\begin{array}{l}7.0(2.0-13.0) \\
6.1(0.9-11.3)\end{array}$ & - & $\begin{array}{l}\text { Multicentric, } \\
\text { prospective } \\
\text { randomized } \\
\text { pivotal study }\end{array}$ \\
\hline $\begin{array}{l}\text { El-Matary } \\
\text { et al. } \\
(2018)^{22}\end{array}$ & Pediatric & 27 & wk 14 & IFX & $\begin{array}{l}\text { Fistula healing (closure } \\
\text { of previous fistula } \\
\text { reported by treating } \\
\text { physician) }\end{array}$ & $12.7(6.6-15.5)$ & $5.4(2.7-8.4)$ & $\geq 12.7$ & $\begin{array}{l}\text { Multicentric, } \\
\text { prospective } \\
\text { inception } \\
\text { cohort study }\end{array}$ \\
\hline $\begin{array}{l}\text { Plevris et al. } \\
(2019)^{24}\end{array}$ & Adults & $\begin{array}{l}29 \text { IFX } \\
35 \text { ADA }\end{array}$ & NR & $\begin{array}{l}\text { IFX } \\
\text { ADA }\end{array}$ & $\begin{array}{l}\text { Primary: fistula healing } \\
\text { (absence of drainage } \\
\text { and no seton) } \\
\text { Secondary: fistula closure } \\
\text { (absence of skin fistula } \\
\text { opening) }\end{array}$ & $\begin{array}{r}8.1 \\
12.6\end{array}$ & $\begin{array}{l}3.2 \\
2.7\end{array}$ & $\begin{array}{l}\geq 7.1 \\
\geq 6.8\end{array}$ & $\begin{array}{l}\text { Single-center, } \\
\text { cross-sectional } \\
\text { retrospective } \\
\text { study }\end{array}$ \\
\hline
\end{tabular}

Values are presented as mean (range).

TNF, tumor necrosis factor; IFX, infliximab; ADA, adalimumab; TDM, therapeutic drug monitoring; NR, not reported; MRI, magnetic resonance imaging.

otics used in isolation. ${ }^{51}$

The evidence described in this narrative review demonstrates that patients with higher serum levels of IFX and ADA may have higher rates of perianal fistula healing and closure. Despite similar conclusions from different studies, there are still questions without answers over this topic. Is dose optimization of anti-TNF agents a warranty of higher serum levels in all CD patients? Clearance of the drugs depends on several factors, as the extension of associated luminal inflammation (e.g., extensive colitis), individual characteristics of each patient, albumin levels, among others. This can explain the need for individualized therapy, with different dose regimens, for different patients, aiming the same outcomes of fistula heal- ing. TDM plays an important role in this treatment personalization.

The designs of the studies previously reviewed also deserve consideration. The publications comprise mostly retrospective cohorts of patients, with serum level dosages in few periods during treatment. Some studies did cross-sectional analyses with retrospective data collection, and most included patients with standard and optimized doses, and no comparison among these 2 strategies are described in all analyses. Only one study did proactive TDM,${ }^{19}$ with the others having blood sample collections in random time periods. It is also not clear if serum levels were measured reactively (with suspicious of loss of response) in most of the studies. These limitations war- 
rant the need for a prospective study, with proactive TDM aiming higher serum levels of the drugs, to check if fistula healing rates can really be improved, with a higher level of scientific evidence.

The evaluation of clinical response, closure or healing of perianal fistulas after anti-TNF therapy in the aforementioned studies varied significantly. Despite the limitations of clinical examinations and presence of purulent discharge, clinical follow-up was not centralized and done by the same assistant physician. The subjectivity of the various definitions of clinical response, added to numerous physicians evaluating this outcome, demonstrates the need for more objective parameters in studies like these.

Another important limitation of most studies is the nonstandardized use of pelvic MRI as primary outcome. The radiologic evaluation of fistula healing was not performed in all studies. Currently, MRI scores are not standardized, and central reading remains a challenge. There are still no well-established universal criteria in pelvic MRI examinations which define closure and healing of fistulas in CD. The modified Van Assche score correlates well with clinical response, but further studies with larger sample of patients are still required for a broader validation of this method. ${ }^{52}$

The studies by Strik et al. ${ }^{21}$ and Plevris et al. ${ }^{24}$ demonstrated similar findings with the intravenous (IFX) and the subcutaneous agent (ADA). The association of higher serum levels of ADA with better clinical outcomes in the Dutch study was clear $(7.4 \mu \mathrm{g} / \mathrm{mL}$ in healed vs. $4.8 \mu \mathrm{g} / \mathrm{mL}$ in active fistulas; $P=$ 0.003). However, patients with optimized ADA dosages (40 mg weekly) had only $30.8 \%$ of healed fistulas as compared to $69.2 \%$ in the regular regimen (40 mg every other week). In the pediatric IMAgINE study ${ }^{23}$ no difference in serum levels of ADA between patients with active versus healed fistulas was observed. These findings illustrate the difficulties in analyzing serum levels from a subcutaneous drug as compared to an intravenous agent. Another important point to be emphasized is that no data is available with TDM in PFCD with biologics with different mechanisms of action, as vedolizumab and ustekinumab.

Most studies also did not differentiate complex versus simple fistulas in the included patients, a limitation of retrospective compilation of data from clinical charts. A comparative analysis would be important in a prospective study, as the surgical approach differs between the 2 types of perianal fistulas in CD. More complex fistulizing disease would theoretically require more active drug, as it is usually associated with a higher inflammatory burden. Different assays used in the studies also limit comparison between them.

Tandon et al., ${ }^{53}$ in a systematic review on optimization strategies for anti-TNF agents in PFCD, identified and selected some of the studies previously described and concluded that there is still a need for better designs for prospective studies. A better understanding of several issues that may cause misinterpretation in the analysis of serum levels and disease activity and the way in which the use of anti-TNFs can be more precisely optimized in these patients is still needed. There was variation in the trough concentrations of IFX in adults that predicted fistula healing (greater than $5 \mu \mathrm{g} / \mathrm{mL}$ to greater than $10.1 \mu \mathrm{g} / \mathrm{mL}$ ), potentially reflecting differences in the timing of serum level collection, assays, the reason for TDM (proactive vs. reactive monitoring), and/or differences in severity of perianal disease. The values that predicted healing of the fistulas may be regarded as the lower limit of the therapeutic drug window in this phenotype of $\mathrm{CD}$. The precise cutoff target level of each drug needs to be better defined. IFX trough concentrations $\geq 10.1 \mu \mathrm{g} / \mathrm{mL}$ in adults can be considered a reasonable target for patients who do not achieve perianal remission. On the other hand, the upper limit of the therapeutic window with no further clinical benefit or with drug toxicity has yet to be adequately defined.

\section{CONCLUSIONS}

Despite the heterogeneity associated to the management of PFCD, with medical and surgical therapies acting together, data regarding higher doses of circulating anti-TNF agents and their association to better outcomes as fistula healing are promising. It should be stated that despite dose optimization of anti-TNF therapy is an important therapeutic strategy for patients who do not achieve fistula healing with standard doses, this cannot guarantee that this will improve fistula healing rates in all cases. Apart from that, due to the favorable shortterm safety of higher serum levels and the lack of other alternative therapeutic options, application of TDM towards more circulating drug can be a valid option aiming fistula healing. The role of TDM in PFCD as a potential strategy still needs more evidence. Prospective studies with proactive TDM, standardized surgical management before induction and objective parameters for outcome measurement, such as MRI radiographic remission, are warranted. 


\section{ADDITIONAL INFORMATION}

\section{Funding Source}

The authors received no financial support for the research, authorship, and/or publication of this article.

\section{Conflict of Interest}

Kotze PG is an editorial board member of the journal but was not involved in the peer reviewer selection, evaluation, or decision process of this article. No other potential conflicts of interest relevant to this article were reported.

\section{Author Contribution}

Conceptualization: Miranda EF. Formal analysis: Miranda EF. Methodology: Nones RB, Kotze PG. Supervision: Miranda EF, Kotze PG. Writing - original draft: Miranda EF, Nones RB, Kotze PG. Writing - review \& editing: Miranda EF, Nones RB, Kotze PG. Approval of final manuscript: all authors.

\section{ORCID}

Miranda EF

Nones RB

https://orcid.org/0000-0003-4011-5112

Kotze PG https://orcid.org/0000-0002-6256-2629 https://orcid.org/0000-0002-2053-5315

\section{REFERENCES}

1. Gomollón F, Dignass A, Annese V, et al. 3rd European evidence-based consensus on the diagnosis and management of Crohn's disease 2016: part 1: diagnosis and medical management. J Crohns Colitis 2017;11:3-25.

2. Peyrin-Biroulet L, Loftus EV Jr, Colombel JF, Sandborn WJ. The natural history of adult Crohn's disease in populationbased cohorts. Am J Gastroenterol 2010;105:289-297.

3. Ng SC, Shi HY, Hamidi N, et al. Worldwide incidence and prevalence of inflammatory bowel disease in the 21st century: a systematic review of population-based studies. Lancet 2018;390:2769-2778.

4. Tang LY, Rawsthorne P, Bernstein CN. Are perineal and luminal fistulas associated in Crohn's disease? A population-based study. Clin Gastroenterol Hepatol 2006;4:1130-1134.

5. Tozer PJ, Burling D, Gupta A, Phillips RK, Hart AL. Review article: medical, surgical and radiological management of perianal Crohn's fistulas. Aliment Pharmacol Ther 2011;33:5-22.

6. Present DH, Rutgeerts $\mathrm{P}$, Targan S, et al. Infliximab for the treatment of fistulas in patients with Crohn's disease. N Engl J Med 1999;340:1398-1405.
7. Sands BE, Anderson FH, Bernstein CN, et al. Infliximab maintenance therapy for fistulizing Crohn's disease. N Engl J Med 2004;350:876-885.

8. Fu YM, Chen M, Liao AJ. A meta-analysis of adalimumab for fistula in Crohn's disease. Gastroenterol Res Pract 2017;2017: 1745692.

9. Colombel JF, Schwartz DA, Sandborn WJ, et al. Adalimumab for the treatment of fistulas in patients with Crohn's disease. Gut 2009;58:940-948.

10. Castaño-Milla C, Chaparro M, Saro C, et al. Effectiveness of adalimumab in perianal fistulas in Crohn's disease patients naive to anti-TNF therapy. J Clin Gastroenterol 2015;49:34-40.

11. Schreiber S, Lawrance IC, Thomsen OØ, Hanauer SB, Bloomfield R, Sandborn WJ. Randomised clinical trial: certolizumab pegol for fistulas in Crohn's disease: subgroup results from a placebo-controlled study. Aliment Pharmacol Ther 2011;33: 185-193.

12. Quaresma AB, Coy CSR, Damião AOMC, Kaplan GG, Kotze PG. Biological therapy penetration for inflammatory bowel disease in Latin America: current status and future challenges. Arq Gastroenterol 2019;56:318-322.

13. Regueiro M, Mardini H. Treatment of perianal fistulizing Crohn's disease with infliximab alone or as an adjunct to exam under anesthesia with seton placement. Inflamm Bowel Dis 2003;9:98-103.

14. Maser EA, Villela R, Silverberg MS, Greenberg GR. Association of trough serum infliximab to clinical outcome after scheduled maintenance treatment for Crohn's disease. Clin Gastroenterol Hepatol 2006;4:1248-1254.

15. Ungar B, Levy I, Yavne Y, et al. Optimizing anti-TNF- $\alpha$ therapy: serum levels of infliximab and adalimumab are associated with mucosal healing in patients with inflammatory bowel diseases. Clin Gastroenterol Hepatol 2016;14:550-557.

16. Chaparro M, Guerra I, Muñoz-Linares P, Gisbert JP. Systematic review: antibodies and anti-TNF- $\alpha$ levels in inflammatory bowel disease. Aliment Pharmacol Ther 2012;35:971-986.

17. Billiet T, Cleynen I, Ballet V, et al. Prognostic factors for longterm infliximab treatment in Crohn's disease patients: a 20year single centre experience. Aliment Pharmacol Ther 2016; 44:673-683.

18. Feuerstein JD, Nguyen GC, Kupfer SS, Falck-Ytter Y, Singh S; American Gastroenterological Association Institute Clinical Guidelines Committee. American Gastroenterological Association Institute Guideline on therapeutic drug monitoring in inflammatory bowel disease. Gastroenterology 2017;153:827834. 
19. Davidov Y, Ungar B, Bar-Yoseph H, et al. Association of induction infliximab levels with clinical response in perianal Crohn's disease. J Crohns Colitis 2017;11:549-555.

20. Yarur AJ, Kanagala V, Stein DJ, et al. Higher infliximab trough levels are associated with perianal fistula healing in patients with Crohn's disease. Aliment Pharmacol Ther 2017;45:933940.

21. Strik AS, Löwenberg M, Buskens CJ, et al. Higher anti-TNF serum levels are associated with perianal fistula closure in Crohn's disease patients. Scand J Gastroenterol 2019;54:453458.

22. El-Matary W, Walters TD, Huynh HQ, et al. Higher postinduction infliximab serum trough levels are associated with healing of fistulizing perianal Crohn's disease in children. Inflamm Bowel Dis 2019;25:150-155.

23. Ruemmele FM, Rosh J, Faubion WA, et al. Efficacy of adalimumab for treatment of perianal fistula in children with moderately to severely active Crohn's disease: results from IMAgINE 1 and IMAgINE 2. J Crohns Colitis 2018;12:1249-1254.

24. Plevris N, Lyons M, Jenkinson PW, et al. Higher adalimumab drug levels during maintenance therapy for Crohn's disease are associated with biologic remission. Inflamm Bowel Dis 2019;25:1036-1043.

25. Denson LA, Curran M, McGovern DPB, et al. Challenges in IBD research: precision medicine. Inflamm Bowel Dis 2019; 25(Suppl 2):S31-S39.

26. Digby-Bell JL, Atreya R, Monteleone G, Powell N. Interrogating host immunity to predict treatment response in inflammatory bowel disease. Nat Rev Gastroenterol Hepatol 2020;17:9-20.

27. Dreesen E, Bossuyt P, Mulleman D, Gils A, Pascual-Salcedo D. Practical recommendations for the use of therapeutic drug monitoring of biopharmaceuticals in inflammatory diseases. Clin Pharmacol 2017;9:101-111.

28. Papamichael K, Rakowsky S, Rivera C, Cheifetz AS, Osterman MT. Association between serum infliximab trough concentrations during maintenance therapy and biochemical, endoscopic, and histologic remission in Crohn's disease. Inflamm Bowel Dis 2018;24:2266-2271.

29. Vande Casteele N, Khanna R, Levesque BG, et al. The relationship between infliximab concentrations, antibodies to infliximab and disease activity in Crohn's disease. Gut 2015;64: 1539-1545.

30. Roblin X, Marotte H, Rinaudo M, et al. Association between pharmacokinetics of adalimumab and mucosal healing in patients with inflammatory bowel diseases. Clin Gastroenterol Hepatol 2014;12:80-84.
31. Carlsen A, Omdal R, Leitao KØ, et al. Subtherapeutic concentrations of infliximab and adalimumab are associated with increased disease activity in Crohn's disease. Therap Adv Gastroenterol 2018;11:1756284818759930.

32. Vermeire S, Dreesen E, Papamichael K, Dubinsky MC. How, when, and for whom should we perform therapeutic drug monitoring? Clin Gastroenterol Hepatol 2020;18:1291-1299.

33. Kelly OB, Donnell SO, Stempak JM, Steinhart AH, Silverberg MS. Therapeutic drug monitoring to guide infliximab dose adjustment is associated with better endoscopic outcomes than clinical decision making alone in active inflammatory bowel disease. Inflamm Bowel Dis 2017;23:1202-1209.

34. Guidi L, Pugliese D, Tonucci TP, et al. Therapeutic drug monitoring is more cost-effective than a clinically based approach in the management of loss of response to infliximab in inflammatory bowel disease: an observational multicentre study. J Crohns Colitis 2018;12:1079-1088.

35. Vande Casteele N, Ferrante M, Van Assche G, et al. Trough concentrations of infliximab guide dosing for patients with inflammatory bowel disease. Gastroenterology 2015;148:13201329.

36. D'Haens G, Vermeire S, Lambrecht G, et al. Increasing infliximab dose based on symptoms, biomarkers, and serum drug concentrations does not increase clinical, endoscopic, and corticosteroid-free remission in patients with active luminal Crohn's disease. Gastroenterology 2018;154:1343-1351.

37. Assa A, Matar M, Turner D, et al. Proactive monitoring of adalimumab trough concentration associated with increased clinical remission in children with Crohn's disease compared with reactive monitoring. Gastroenterology 2019;157:985996.

38. Papamichael K, Vajravelu RK, Vaughn BP, Osterman MT, Cheifetz AS. Proactive infliximab monitoring following reactive testing is associated with better clinical outcomes than reactive testing alone in patients with inflammatory bowel disease. J Crohns Colitis 2018;12:804-810.

39. Fernandes SR, Bernardo S, Simões C, et al. Proactive infliximab drug monitoring is superior to conventional management in inflammatory bowel disease. Inflamm Bowel Dis 2020;26:263-270.

40. Dreesen E, D'Haens GR, Baert FJ, et al. Infliximab exposure predicts superior endoscopic outcomes in patients with active Crohn's disease: pharmacokinetic-pharmacodynamic analysis of TAILORIX. J Crohns Colitis 2018;12 (Suppl 1): S063S064.

41. Negoescu DM, Enns EA, Swanhorst B, et al. Proactive vs reac- 
tive therapeutic drug monitoring of infliximab in Crohn's disease: a cost-effectiveness analysis in a simulated cohort. Inflamm Bowel Dis 2020;26:103-111.

42. Pérez I, Fernández L, Sánchez-Ramón S, et al. Reliability evaluation of four different assays for therapeutic drug monitoring of infliximab levels. Therap Adv Gastroenterol 2018;11: 1756284818783613.

43. Vande Casteele N, Gils A. Pharmacokinetics of anti-TNF monoclonal antibodies in inflammatory bowel disease: adding value to current practice. J Clin Pharmacol 2015;55 Suppl 3:S39-S50.

44. Vande Casteele N, Baert F, Bian S, et al. Subcutaneous absorption contributes to observed interindividual variability in adalimumab serum concentrations in Crohn's disease: a prospective multicentre study. J Crohns Colitis 2019;13:12481256.

45. Vermeire S, Gils A, Accossato P, Lula S, Marren A. Immunogenicity of biologics in inflammatory bowel disease. Therap Adv Gastroenterol 2018;11:1756283X17750355.

46. Van Stappen T, Vande Casteele N, Van Assche G, Ferrante M, Vermeire S, Gils A. Clinical relevance of detecting anti-infliximab antibodies with a drug-tolerant assay: post hoc analysis of the TAXIT trial. Gut 2018;67:818-826.

47. Papamichael K, Cheifetz AS, Melmed GY, et al. Appropriate therapeutic drug monitoring of biologic agents for patients with inflammatory bowel diseases. Clin Gastroenterol Hepatol 2019;17:1655-1668.

48. Yarur AJ, Jain A, Sussman DA, et al. The association of tissue anti-TNF drug levels with serological and endoscopic disease activity in inflammatory bowel disease: the ATLAS study. Gut 2016;65:249-255.

49. Bemelman WA, Warusavitarne J, Sampietro GM, et al. ECCOESCP consensus on surgery for Crohn's disease. J Crohns Colitis 2018;12:1-16.

50. Kotze PG, Shen B, Lightner A, et al. Modern management of perianal fistulas in Crohn's disease: future directions. Gut 2018;67:1181-1194.

51. De Groof EJ, Sahami S, Lucas C, Ponsioen CY, Bemelman WA, Buskens CJ. Treatment of perianal fistula in Crohn's disease: a systematic review and meta-analysis comparing seton drainage and anti-tumour necrosis factor treatment. Colorectal Dis 2016;18:667-675.

52. Van Rijn KL, Lansdorp CA, Tielbeek JAW, et al. Evaluation of the modified van Assche index for assessing response to antiTNF therapy with MRI in perianal fistulizing Crohn's disease. Clin Imaging 2020;59:179-187.

53. Tandon P, Rhee GG, Schwartz D, McCurdy JD. Strategies to optimize anti-tumor necrosis factor therapy for perianal fistulizing Crohn's disease: a systematic review. Dig Dis Sci 2019; 64:3066-3077. 